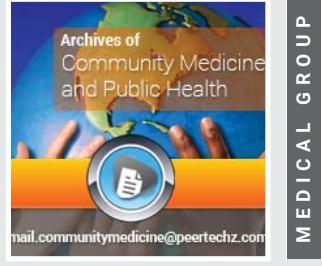

\title{
Dysarthria: Definition, clinical contexts, neurobiological profiles and clinical treatments
}

Received: 25 June, 2020

Accepted: 20 July, 2020

Published: 21 July, 2020

*Corresponding author: Giulio Perrotta, Psychologist sp.ed Strategic Psychotherapist, Forensic Criminologist, Jurist sp.ing SSPL, Lecturer, Essayist, Italy, E-mail: giuliosr1984@hotmail.it https://www.peertechz.com

\section{Check for updates}

\section{Giulio Perrotta* \\ Psychologist sp.ed Strategic Psychotherapist, Forensic Criminologist, Jurist sp.ing SSPL, Lecturer, Essayist, Italy}

\begin{abstract}
Starting from the general concept of Dysarthria, the present work focuses on the clinical, neurobiological, and functional aspects of the morbid condition, suggesting a multidimensional treatment between physiotherapy, psychotherapy, and rehabilitation exercises for lost skills.
\end{abstract}

\section{Contents of the manuscript}

"Dysarthria" is a motor language disorder that derives from a neurological injury involving the motor component of language and is characterized by a poor articulation capacity of the phonemes; in practice, dysarthria is a condition in which problems are inherent in the muscles responsible for producing language, often to the point of making words extremely difficult. Any type of language subsystem (breathing, phonation, resonance, prosody and articulation) can be involved and lead to impairments in the intelligibility, audibility, naturalness, and effectiveness of voice communication [1-4].

Therefore, dysarthria [5]:

a) It is not connected to any problem of language comprehension;

b) Does not include speech disorders related to structural abnormalities, such as cleft lip or cleft palate;

c) Differs from speech apraxia, which refers to problems related to the planning and programming aspect of the motor system linked to language;

d) Differs from aphasia which is instead a disorder of the content (and not of the articulation) of language;

e) Refers to the partial loss of the aforementioned capacity (when the loss is total, it will be referred to as "anarthria"); f) May affect a single system or be more commonly reflected in the interest of multiple vocal motor systems. Patients experience difficulties in all specific components of the phonemic joint: synchronization, vocal quality, intonation, volume, breath control, speed, strength, constancy, range and tone.

The etiological causes of dysarthria can be manifold, including $[4,5-8]$ :

a) Heavy metal poisoning.

b) Metabolic dysfunctions and pathologies affecting the glands.

c) Abuse or intoxication or systematic hypersensitivity to certain drugs (for example, antipsychotics, opioids, hallucinogens, and benzodiazepines).

d) Serious intoxication by narcotic and/or alcoholic substances.

e) Neurodegenerative and oncological diseases affecting the central and / or peripheral nervous tissue.

f) Traumatic and vascular brain injuries (capable of causing dysfunctions affecting the motor or somatosensory cerebral cortex, corticobulbar pathways, cerebellum, nuclei of the base -putamen, pale globe, caudate nucleus, substantia nigra, brain stem -da which originate the 
cranial nerves-, or the neuromuscular junction - motive plate, for example in diseases such as myasthenia gravis), capable of weakening the affected tissue or provoking weakness, paralysis or loss of coordination of the motor system of speech. These effects, in turn, may be able to hinder the organic functioning of the tongue, throat, lips or diaphragmatic muscles, also associated with swallowing (causing, in comorbidity, dysphagia) or even the cranial nerves that control these muscles, such as the motor branch of the trigeminal nerve $(\mathrm{V})$, the facial nerve (VII), the glossopharyngeal nerve (IX), the vagus nerve (X), and the hypoglossal nerve (XII) [9].

These hypotheses involve injuries in key areas of the brain involved in the planning, execution, or regulation of motor activities of the different phonation-related skeletal muscles [2].

Dysarthria can be classified in different ways depending on the presentation of symptoms. We therefore distinguish the following six forms [10].

a) "Spastic", resulting from bilateral damage to the superior motor neuron.

b) "Flabby", resulting from bilateral or unilateral damage to the motor neuron.

c) "Ataxic", resulting from damage to the cerebellum. It is an acquired neurological and sensory-motor language deficit. Since the regulation of fine movements is a primary function of the cerebellum, it is therefore believed that damage to the upper cerebellum or cerebellar peduncle can produce this form of dysarthria in ataxic patients. Some of the most consistent anomalies observed in patients with ataxic dysarthria are the alterations of the normal temporal pattern, with prolongation of some segments of the language and a tendency to equalize the duration of the pronunciation of the syllables. As the severity of dysarthria increases, the patient can also stretch multiple segments of speech as well as increase the degree of elongation of each segment. Common clinical features of ataxic dysarthria include abnormalities in vocal modulation, inaccurate consonants, irregular articulatory interruptions, distorted vowels, explosive speech, equal and excessive emphasis, inappropriate intervals, and silences.

d) "Unilateral superior motor neuron", characterized by milder symptoms compared to bilateral damage.

e) "Hyperkinetic"/"hypokinetic", resulting from damage in certain areas of the basal ganglia, such as in Huntington's disease or parkinsonism.

f) "Mixed", characterized by symptoms typical of more than one type of dysarthria. This is also the most common form, statistically, as neurological tissue damage is often localized across multiple regions and areas of the nervous system.
The articulatory disorders resulting from dysarthria are treated with specific speech therapy, to correct or improve the management of deficits in speed (of articulation), in prosody (appropriate emphasis and inflection, problems that are found, for example, in apraxia of speech, in lesions of the right cerebral hemisphere, etc.), in the intensity (volume of the voice, typically damaged in case of hypokinetic dysarthria, as occurs in Parkinson's disease), in resonance (ability to alter the "vocal tract" and spaces of resonance, or those cavities containing air arranged in series or parallel - from the glottis to the lips, to the nasopharynx - which are put into vibration at the level of the vocal cords for a correct emission of the sound of the language) and in the phonation (control of the strings vowels for an adequate quality of the voice and the emission of specific ranges of sounds, also through the control of the airways). These treatments generally involve a series of exercises aimed at increasing the strength and control of the articulatory muscles (which may be flabby and weak, or too underdeveloped and difficult to put into action), and the use of language techniques alternatives to increase speech intelligibility (i.e. to improve speech understanding by others). Depending on the severity of the dysarthria, another possibility includes learning to use a computer or using cards depicting words or symbols (flip cards) to be able to communicate more effectively [5,10-16].

Therefore, the treatment [2,4] of dysarthria varies according to the site of the lesion: depending on the type of dysarthria, activities will be carried out that allow the patient to reduce the disorder that has arisen. The diagnosis, therefore, involves computed tomography or magnetic resonance imaging and a series of tests in which some fundamental parameters are considered: comprehension, repetition, production, reading, writing, and naming. As the tongue, mandible, trachea, vocal cords, epiglottis, esophagus, lips, and larynx are involved, the treatment starts with the setting of a correct costdiaphragmatic breathing and continues with specific activities that allow the patient to improve his skills in phonation, resonance, articulation, diakinesis (i.e. the ability to make rapid movements in succession and alternately), rhythm and prosody of speech.

In particular, there are three methods to intervene clinically on dysarthria $[2,4]$ :

1) "Relaxation and breathing techniques", which are necessary to train the patient functionally, also intervening on pathological conditions of anxious and nervous origin;

2) "Vocalization techniques", neurolinguistic and logopedic matrix, to accustom the phonatory apparatus to a better physical and emotional management of the exercises;

3) "Rhythmic voice techniques", to favor the best possible result, according to the severity of the morbid condition;

4) "Correct posture and possible postural corrections" (for example, the mobilization of the scapular cingulate and the vertebral axis), to favor the above-mentioned exercises. 
Some exercises that are proposed concern precisely these critical elements $[17,18]$ :

A) Sit or lie down in a comfortable position and close your eyes: try to perceive your breathing: where it happens, how strong it is; leave your breathing calm, do not force it; try to perceive what the individual parts of the body are like: feet, legs, seat, hands, arms, neck, belly, back, face; try to understand if they are hot, cold, light, heavy, painful, tense, big, thin.

B) Sit on a chair with your feet firmly on the ground, place your knees at 90 degrees and bring your pelvis back and forth concentrating on the point of rotation.

C) Lift and lower your shoulders; lift your shoulders and drop them after 5 seconds; lift and lower one shoulder at a time; push your shoulders forwards/backward; make circles with your shoulders; push your chin towards your chest and then return to a neutral position; bend your head to the right and left-leaning on your shoulders; look over your right and then your left shoulder; stretch your arms upwards; make your hands and arms "shake".

D) Lie down comfortably with a heavy book on your belly; watch the book rise and fall with your breathing; put a hand on your belly and try to perceive its movements while breathing; inspire with your nose, hold your breath for a moment, then slowly exhale through your mouth; inhale through your nose and slowly exhale making a sssssss..., fffffff..., schschsch (long); make s-s-s...,f-f-f...,sch-sch-sch (short); sing melodies known by the "mmmm. "; blowing imagining to extinguish many candles; imagining to inhale deeply with the nose the scent of a rose; deeply inspiring and pronouncing a prolonged vowel (ahhhh...ehhhh...ihhhh...ohhhh...uhhh) and then stopping before the air ends.

E) Tighten the teeth strongly - all the muscles of the face are activated; squeeze the eyes strongly - all the muscles of the face are activated; alternate an angry expression by wrinkling the forehead with a surprised expression by opening the eyes wide and raising the eyebrows; massage the face; yawn.

F) Open and close the mouth showing the teeth; move the jaw right / left; forward / backward; with the mouth open / closed exaggerate chewing.

G) With closed lips: alternatively iron and make a circle with the lips showing the teeth: alternatively iron and make a circle with the lips; alternatively, pull the corner of the mouth aside; whistle.

H) Swell the cheeks keeping the lips tight - no air should come out; vacuum the cheeks to make them explode in a sound kiss; move the air from one cheek to the other.

I) Alternatively pull out / bring the tongue back in; mouth slightly open, push the tongue alternately left and right; alternatively "clean" the upper lip than lower lip; with the mouth open, lick the lips, changing the direction of the circle; tongue towards the nose / the chin; clean the teeth with the tongue; count the teeth with the tongue; massage the palate/ cheeks with the tongue; push the tip of the tongue (front, side, top, bottom) against a spatula; snap with the tongue (like a horse); press the tongue against the cheeks.

J) Gradually increase the volume by thinking about different distances of the interlocutor using short sentences Es: How's it going? Be good! Come here! All right! You answer it! It's not time. Is it ready?; vary the intensity of the vowels; vary the frequency of the vowels; go up and down in frequency with a "mhhh"; sound chewing; associate the /tr/ to the vowels, keeping them as stable as possible; practice the strongest phonetic attacks; practice the softer attacks by placing nasal sounds in front $(\mathrm{m} / \mathrm{n})$.

K) Emphasize the keyword in a sentence; lower or increase the tone of voice, "play" with questions and answers; slow down the eloquence by spelling out the words starting from short words to get to sentences; speak following the rhythm of a metronome.

Etiology, the degree of neuropathy, the existence of comorbidities, and individual response all play a role in the effect that the disorder has on the individual's quality of life. The severity of the disorder is variable, from an occasional difficulty in articulating the verbal language to a completely incomprehensible speech; for this reason, it is suggested to combine a specific cognitive-behavioral or strategic psychotherapy with speech therapy [19], also because dysarthria in itself, as a pathological state, in its clinical sense may be able to negatively affect other psychological conditions, previous or concomitant, or feed the development of new psychopathologies, more or less acute in the manifestations, as happens in anxious states [20] and depressants [21], in posttraumatic stress events [22] caused by serious psychological trauma [23], in panic attacks [24], in sleep disturbances on a psychosomatic basis [25], in obsessive disorders-compulsive [26] and psychopathological personality disorders in general. Dysarthria is also one of the causes that increases suicidal risk [27], especially concerning the subjective value of language for the patient. The best clinical approach is therefore the combination of speech therapy, psychotherapy, and targeted pharmacological techniques $[1,2,4]$.

\section{References}

1. Perrotta G (2019) Psicologia clinica. Luxco Ed., 1th ed.

2. Angelini C, Battistin L (2019) Neurologia clinica. Società Editrice Esculapio. Link: https://bit.ly/39dRoiu

3. Perrotta G (2019) Specific learning and language disorders: definitions, differences, clinical contexts, and therapeutic approaches. J Addi Adol Beh 2: 11. Link: https://bit.ly/2DYzNPX

4. Kandel ER, Schwartz J, Jessel T, Siegelbaum SA, Hudspeth AJ (2017) Principi di Neuroscienze. V ed., Casa Editrice Ambrosiana.

5. Duffy J (2005) Motor speech disorders: Substrates, Differential diagnosis and Management, St. Louis, Mo, Elsevier Mosby. Link: https://bit.ly/2BlkvnC

6. MacKenzie C (2011) Dysarthria in stroke: A narrative review of its description and the outcome of intervention. International Journal of Speech-Language Pathology 13: 125-136. Link: https://bit.ly/2WEbk9l 
7. Eigentler A, Rhomberg R, Nachbauer W, Ritzer I, Poewe W, et al. (2011) The scale for the assessment and rating of ataxia correlates with dysarthria assessment in Friedreich's ataxia. J Neurol 259: 420-426. Link: https://bit.ly/2WFN1HS

8. Caplan LR (2013) Ataxia in patients with brain infarcts and hemorrhages Handb Clin Neurol 103: 147-160. Link: https://bit.ly/30qumB2

9. Spencer KA, Slocomb DL (2007) The neural basis of ataxic dysarthria Cerebellum 6: 58-65. Link: https://bit.ly/30A5Ttf

10. Ogawa K, Yoshihashi H, Suzuki Y, Kamei S, Mizutani T (2010) Clinical study of the responsible lesion for dysarthria in the cerebellum. Intern Med 49: 861864. Link: https://bit.ly/3fO1Wr1

11. O'Sullivan SB, Schmitz TJ (2007) Physical rehabilitation. $5^{\text {th }}$, Philadelphia, F. A Davis Company. Link: https://bit.ly/2E57tvx

12. Kent RD, Netsell R, Abbs JH (2012) Acoustic characteristics of dysarthria associated with cerebellar disease. J Speech Hear Res 22: 627-648. Link: https://bit.ly/39fT8aY

13. Goda S (1963) Communicating with the aphasic or dysarthric patient. Am J Nurs 63: 80-84. Link: https://bit.ly/3jol1IV

14. Levin HS, Grossman RG, Sarwar M, Meyers CA (1981) Linguistic recovery afte closed head injury. Brain Lang 12: 360-374. Link: https://bit.ly/2CUze9g

15. Yu-Tsai W, Kent RD, Duffy JR, Thomas JE (2009) Analysis of Diadochokinesis in Ataxic Dysarthria Using the Motor Speech Profile Program ${ }^{\text {TM }}$. Folia Phoniatr Logop 61: 1-11. Link: https://bit.ly/3jorzB4

16. Palmer R, Enderby P, Hawley M (2007) Addressing the needs of speakers with longstanding dysarthria: computerized and traditional therapy compared. Int $\mathrm{J}$ Lang Commun Disord 42: 61-79. Link: https://bit.ly/32AxTPX

17. Schindler A, Amitrano A, Ruoppolo G (2012) Manuale di foniatria e logopedia, SEU ed. Link: https://bit.ly/3hk6wh5
18. Castelli E, Marotta L (2020) Manuale di logopedia in età evolutiva. Erikson Ed

19. Perrotta G (2020) The strategic clinical model in psychotherapy: theoretical and practical profiles. J Addi Adol Behav 3: 5.

20. Perrotta G (2019) Anxiety disorders: definitions, contexts, neural correlates and strategic therapy. J Neuro Neurosci 6: 046. Link: https://bit.ly/2ZpWNQG

21. Perrotta G (2019) Depressive disorders: Definitions, contexts, differential diagnosis, neural correlates and clinical strategies. Peertechz Arch Depress Anxiety 5: 009-033. Link: https://bit.ly/2zSl1Zh

22. Perrotta G (2019) Post-traumatic stress disorder: Definition, contexts, neura correlations and cognitive-behavioral therapy. J Pub Health Catalog 2: 40-47. Link: https://bit.ly/2WMQCo1

23. Perrotta G (2020) Psychological trauma: definition, clinical contexts, neura correlations and therapeutic approaches. Curr Res Psychiatry Brain Disord CRPBD-100006. Link: https://bit.ly/3gbRCto

24. Perrotta G (2019) Panic disorder: definitions, contexts, neural correlates and clinical strategies. Curr Trends Clin Med Sci 1: 2019. Link: https://bit.ly/2Xk0d4T

25. Perrotta G (2019) Sleep-wake disorders: Definition, contexts and neural correlations. J Neurol Psychol 7: 09. Link: https://bit.ly/2AJjBAX

26. Perrotta G (2019) Obsessive-Compulsive Disorder: definition, contexts, neural correlates and clinical strategies. J Neurol 1: 08-16. Link: https://bit.ly/394tJRm

27. Perrotta G (2020) Suicidal risk: definition, contexts, differential diagnosis neural correlates and clinical strategies. J Neuroscience and Neurological Surgery 6: 114. Link: https://bit.ly/2WssTcl

\section{Discover a bigger Impact and Visibility of your article publication with} Peertechz Publications

\section{Highlights}

* Signatory publisher of ORCID

- Signatory Publisher of DORA (San Francisco Declaration on Research Assessment)

* Articles archived in worlds' renowned service providers such as Portico, CNKI, AGRIS TDNet, Base (Bielefeld University Library), CrossRef, Scilit, J-Gate etc

* Journals indexed in ICMJE, SHERPA/ROMEO, Google Scholar etc.

* OAI-PMH (Open Archives Initiative Protocol for Metadata Harvesting)

* Dedicated Editorial Board for every journal

* Accurate and rapid peer-review process

* Increased citations of published articles through promotions

* Reduced timeline for article publication

Submit your articles and experience a new surge in publication services (https://www.peertechz.com/submission).

Peertechz journals wishes everlasting success in your every endeavours.

Copyright: (c) 2020 Perrotta G. This is an open-access article distributed under the terms of the Creative Commons Attribution License, which permits unrestricted use, distribution, and reproduction in any medium, provided the original author and source are credited. 